BIOLOGICAL PROGRESS AND THE USE OF NITROGEN BY CEREAL VARIETIES

\author{
Ludwik Wicki ${ }^{1}$ \\ Warsaw University of Life Sciences - SGGW, Faculty of Economic Sciences, Poland
}

\begin{abstract}
Nowadays, the need for sustainable development of agriculture is emphasized. The sector must not only supply enough food world population and provide income for farmers, but also reduce its impact on the environment. The possibility of achieving these two objectives together may result from the introduction of biological innovations in the form of new crop varieties, which use nutrients more efficiently or are better adapted to the production conditions. The aim of the work is to determine the changes in the level of nitrogen utilization from mineral fertilizers by winter wheat and rye varieties introduced for cultivation in Poland in 1998-2014. The results of varietal experiments carried out by RCCT were used in the research. The changes in the productivity level of nitrogen fertilization were determined for the tested varieties. It was found that newer varieties of winter wheat and rye were characterized by higher grain production per $1 \mathrm{~kg}$ of nitrogen in mineral fertilizers. Varieties from 2012-2014, compared to those from 1998-2000, were characterized by higher productivity by $4 \mathrm{~kg}$ of grain / $1 \mathrm{~kg}$ of $\mathrm{N}$ and $10 \mathrm{~kg}$ of grain / $1 \mathrm{~kg}$ of $\mathrm{N}$, respectively for winter wheat and rye. This could significantly contribute to the reduction of emissions from agricultural production, since the estimated reduction in the use of nitrogen fertilizers in cereal production was over $5 \%$ for the volume of production from 2017. It was found that introducing new varieties that use nitrogen fertilization more efficiently can be an important factor leading to reducing emissions from agriculture and to increasing agricultural production without increasing pressure on the natural environment.
\end{abstract}

Key words: biological innovations, external effects, bioeconomy, nitrogen emission, nitrogen productivity. JEL code: Q01, Q16, Q55.

\title{
Introduction
}

Economy, including agriculture, is changing constantly. For many years, innovations introduced in various spheres of agricultural activity have led to a constant increase in productiveness of the production factors engaged (Wicki, 2018a). Innovations involve the production technologies applied, machines, fertilizers, plant protection agents, as well as plants and animals. In plant production, biological progress is ensured by cultivation and selection for agricultural production of plant varieties that are constantly being improved. Over the long-term perspective, in developed countries, about $50 \%$ of increase in cereal yield has been achieved thanks to plant cultivation and new varieties (Duvick, 2005; Thirtle, 1995). In Poland, in years 2006-2017, introduction of innovations consisting of new varieties explained 20 to $60 \%$ of increase in cereal yield, depending on the species (Wicki, $2017 a ; 2018 b)$. In new varieties, various features are developed, including those associated with better use of nitrogen and its contribution to yield. On the average, agricultural plants use only $33 \%$ of available nitrogen (Raun and Johnson, 1999). Modern varieties e.g. of wheat, although not always characterized by better nitrogen utilization, are usually more capable of using its high doses, which results in high yield, including under conditions of low-intensity and organic farming (Guarda, Padovan and Delogu, 2004). The genes of these plants are adapted to better use of nitrogen (Van Sanford and MacKown, 1986; Ortiz-Monasterio at al. 1997; Le Gouis at al., 2000). Traditional varieties, adapted to low nitrogen content in the soil, can be used in extensive farming and constitute a valuable source of genes in plant cultivation (Dawson, Huggins and Jones, 2008).

Increase in agricultural production is necessary due to the growing demand for food and limited land resources (Hitz, Clark and Van Sanford, 2017), which calls for use of high-yielding varieties (Stevenson at al., 2013) and engagement of high expenditures. This generates higher production costs and increases the risk of environmental pollution (Guarda, Padovan and Delogu, 2004).

\footnotetext{
${ }^{1}$ corresponding author: e-mail: ludwik_wicki@sggw.pl; dr habil., WULS professor, ORCID: 0000-0002-7602-8902
} 
At present, an important objective is to achieve a higher level of utilization of nitrogen from mineral and organic fertilizers, translating to higher yield per unit of fertilizer. To produce 1 ton of nitrogen fertilizer, about 870 cubic meters of natural gas is used. There is also energy used in transport and in the fertilization process, as well as fuel and labour expenditures. In order to limit the costs of fertilizing and reduce the potential negative environmental impact, it is necessary to search for new solutions. These include precision farming, plant breeding oriented at varieties, which make better use of nitrogen and are characterized by a positive response to more intensive fertilization (Dawson, Huggins and Jones, 2008). This may contribute to reduction of plant demand for nitrogen while maintaining a constant yield of grain and protein, which, however, does not relate directly to the impact of excessive nitrogen fertilization on the environment. Moreover, it has been estimated that expenditures for fertilizers amount even to $50 \%$ of cost of cereal production (Klikocka at al., 2011), and nitrogen balance in agriculture depends mainly on fertilization level (Jankowiak at al., 2010; Tkaczyk at al., 2018). Higher plant yield, on the other hand, is also associated with greater sequestration of atmospheric carbon by plants, and thus total greenhouse gas emission may grow at a slower pace than production (Faber and Jarosz, 2018). According to Kopinski (2018), in Poland, in years 2002-2016, GHG emission from agriculture was reduced despite increase in production. Factors that contributed to this were increase in utilization of modern plant varieties and their yield potential (Wicki, 2016; 2017b), and application of proper production techniques in farming.

The aim of improving effectiveness of use of fertilizers has some environmental aspects as well. At present, the level and causes of greenhouse gas emission from agricultural production is being analysed thoroughly, indicating the need to reduce emission (Lenerts at al., 2017; Naglis-Liepa at al. 2018). Some of the postulated actions would have to result in limiting of production and a disadvantageous change in land use structure. Achievement of environmental objectives in agriculture is usually accompanied by limiting of production objectives (Czyzewski and Staniszewski, 2018; Kraciuk, 2018), and from the perspective of sustainable development, it is necessary to search for solutions that would make it possible to generate environmental public goods by farming without limiting production (Danilowska, 2015; Golebiewska and Pajewski 2018; Malazewska, 2015). Another benefit of varieties improvement is the possibility of choosing better plants in terms of their adaptation to soil and climatic conditions, which reduces the production and economic risk in agriculture (Wicka, 2018).

Possibilities of achieving higher production thanks to more effective use of fertilizers are thus due to achievements in plant cultivation and application of proper farming techniques (Gastal at al., 2015). As a result, it is possible to achieve the objectives in productivity, economy and environment protection. Thus, these activities are aimed at sustainable development of farming.

\section{Aim and methods}

The objective of this study is to determine the changes in level of utilization of nitrogen from mineral fertilizers by winter wheat and rye varieties introduced to production in Poland in years 19982014.

The following research tasks were completed: 1) gross productivity of nitrogen fertilization was determined for winter wheat and rye varieties introduced in individual years of the examined period; 2 ) the trend in gross productivity of nitrogen fertilization depending on variety age was specified.

The source of data was information published annually by the Research Centre for Cultivar Testing (RCCT) on yields of individual varieties under conditions of a field experiment. The analysis period encompassed years 2005-2017, and the comparison involved those varieties, which were tested for 
at least two years. In total, the comparison included 40 varieties of rye and 101 varieties of winter wheat. Information was gathered on yield and fertilization level for each variety in each of the years analysed. For each variety and year, grain yield $(Y)$ was determined per $1 \mathrm{~kg}$ of nitrogen in mineral fertilizer $(N)$. Then, for each year analysed, average nitrogen utilization effectiveness was determined $(\mathrm{Y} / \mathrm{N})$ for varieties introduced in farming in a given year. Finally, dependence between year of introduction of variety to production and the nitrogen utilization effectiveness was determined using the linear regression function, estimated on the basis of the ordinary least squares method (OLSM).

\section{Research results and discussion}

In field experiments conducted in Poland, the yields of different cereal varieties amount to 70$100 \mathrm{dt}$ per hectare. Yield fluctuations are recorded depending on the weather, e.g. draught or severe winter conditions with very low temperatures. Figure 1 presents the level of yield of winter wheat and rye in field experiments in years 2005-2017. Fertilization intensity and production technology in the experiments did not change substantially in the period analysed. Nitrogen fertilization in individual years amounted to 80 to $90 \mathrm{~kg} \mathrm{~N} /$ ha for rye and 104 to $114 \mathrm{~kg} \mathrm{~N} /$ ha for wheat

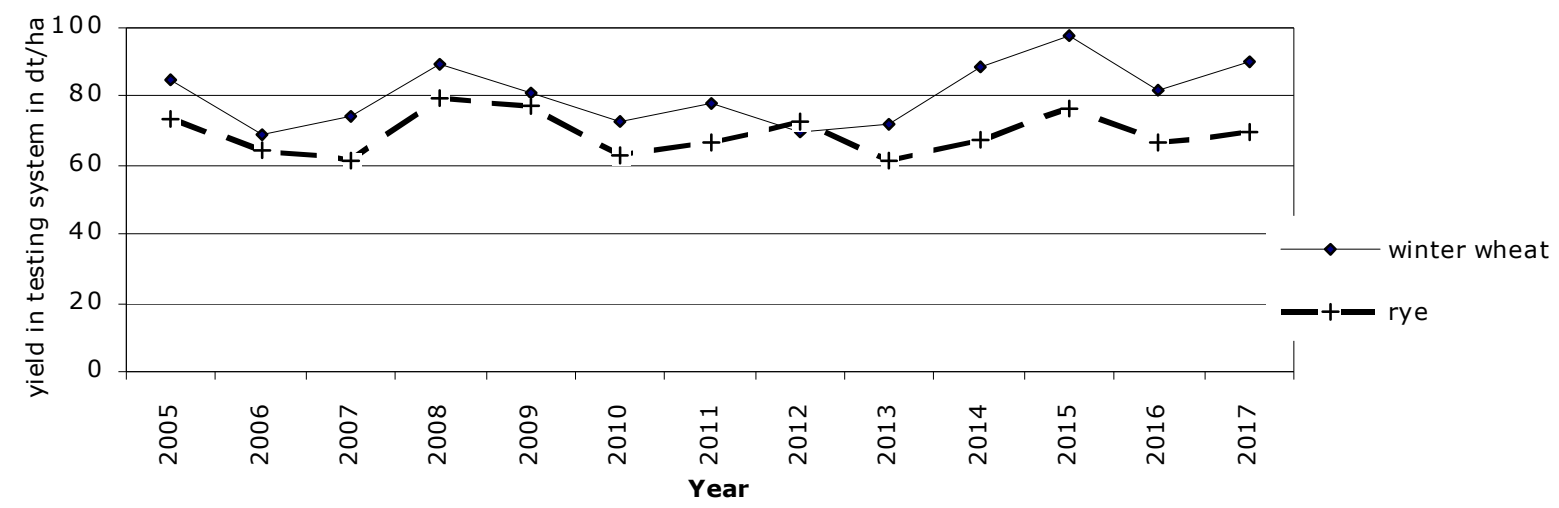

Source: author's drawing based on data of RCCT (COBORU, 2005-2017)

Fig. 1. Cereals yield in field trials in variety testing system (2005-2017)

Figure 2 presents changes in the nitrogen utilization effectiveness indicator, expressed in kilograms of cereal per kilogram of nitrogen from mineral fertilizer. It should be kept in mind that this analysis does not take into account availability of nitrogen from other sources than mineral fertilizers.

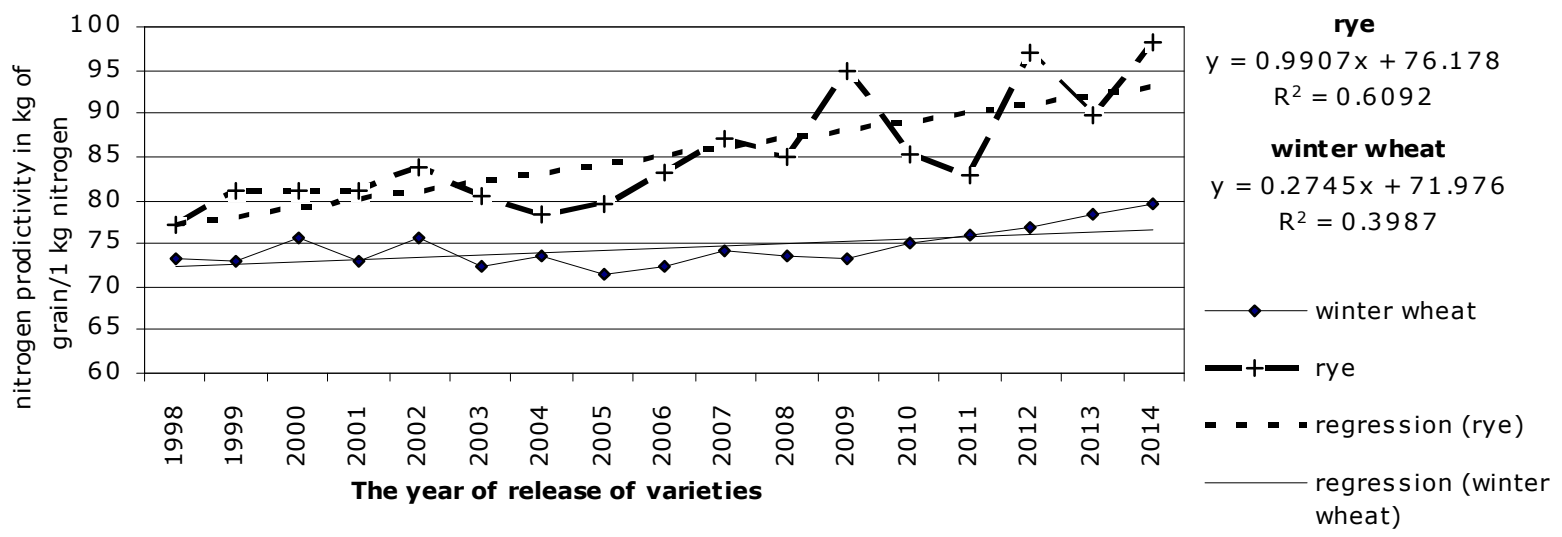

Source: author's calculations based on data of RCCT (COBORU, 2005-2017)

Fig. 2. Nitrogen productivity ratio for varieties depending on the year of releasing of the variety for production (varieties released in 1998-2014) for winter wheat and rye varieties (nitrogen productivity is averaged for years of testing) 
Results presented in Figure 2 show positive relationship between production of grain from $1 \mathrm{~kg}$ of nitrogen in mineral fertilizers and time of release of varieties. This relationship is closer for rye and weaker for winter wheat. The level of explained variability of nitrogen utilization effectiveness indicator by year of release of varieties equals about $60 \%$ for rye and almost $40 \%$ for winter wheat. Our findings indicate that introduction of new varieties causes growth of productivity of nitrogen fertilization.

For wheat varieties introduced in production in years 1998-2000, average nitrogen productivity amounted to $74 \mathrm{~kg}$ of grain per $1 \mathrm{~kg}$ of nitrogen. Varieties introduced in the subsequent years featured increasing productivity, wherein average productivity of nitrogen for varieties registered in years 2012-2014 was higher by $4.4 \mathrm{~kg}$ of grain per $1 \mathrm{~kg} \mathrm{~N}$ in comparison with varieties registered in years 1998-2000.

For rye, gross productivity of nitrogen fertilization was higher than for wheat, mainly due to introduction of high-yield hybrid varieties (F1). For rye varieties registered in years 1998-2000, average gross productivity of nitrogen fertilization amounted to about $80 \mathrm{~kg}$ of grain per $1 \mathrm{~kg} \mathrm{~N}$. Varieties introduced in years 2000-2005 did not feature a substantially higher nitrogen utilization effectiveness. Only varieties registered since 2007, including hybrid varieties, are characterized by higher productivity. On the average, nitrogen utilization ratio for rye varieties registered in years $2012-2014$ is higher by $14 \mathrm{~kg}$ of grain / $1 \mathrm{~kg} \mathrm{~N}$ in comparison with those registered in years 19982000. Like in the case of wheat, we can only refer here to an average tendency, as varieties introduced in the subsequent years did not always feature a higher value of the examined trait in comparison with the older ones. On the average, as the variety age reduced by one year, the nitrogen utilization ratio increased by $1 \mathrm{~kg}$ of grain / $1 \mathrm{~kg} \mathrm{~N}$.

For rye, varieties can be divided into two groups: traditional and hybrid varieties. The first hybrid varieties of rye were introduced in Poland in years 2001-2003, and the subsequent - in years 20072014. Productivity ratio for nitrogen from mineral fertilizers for varieties from years 2001-2003 averaged $89 \mathrm{~kg}$ of grain /1 kg N, and for newer varieties, introduced in years 2012-2014, as much as $97 \mathrm{~kg}$ of grain/1 kg N. It should be kept in mind, however, that these varieties are not appropriate for low intensity production.

Traditional rye varieties were introduced throughout the entire period of analysis. Nitrogen fertilization productivity ratio increased for these varieties at the pace of $0.38 \mathrm{~kg}$ with decrease variety age by one year, taking into account the variety registration years. On the average, productivity of nitrogen from mineral fertilizers increased for population rye varieties introduced in years $1998-2014$ from 79 to $84 \mathrm{~kg}$ of grain /1 kg N. This is half less than for all rye varieties together, which means that progress in terms of the cultivars being examined was mainly due to introduction of hybrid varieties.

On the basis of the recorded changes in utilization of nitrogen from mineral fertilizers by cereals, hypothetical reduction in nitrogen fertilizers in Poland was determined due to application of varieties introduced in years 2012-2014 instead of those registered in years 1998-2000. The reference level was the average area and level of production of cereals from years 2015-2017. For rye, it was assumed that in the first period, only traditional varieties were used, which in the latter period occupied $95 \%$ of total cultivation area. This is a simplified calculation, as it does not take into account the response of each individual variety to changes in nitrogen fertilization level and the variety structure in field production. Thus, it was assumed that differences between the older and newer 
varieties would be the same in production as in experiments. The calculation results have been presented in Table 1.

\begin{abstract}
Estimated reduction of nitrogen consumption from mineral fertilizers as a result of the introduction of new varieties on example of production volume in years 2015-2017
\end{abstract}

\begin{tabular}{|c|c|c|c|c|c|c|}
\hline \multirow{2}{*}{ Item } & \multirow{2}{*}{$\begin{array}{l}\text { Area of } \\
\text { production in } \\
\text { '000 ha }\end{array}$} & \multirow{2}{*}{$\begin{array}{l}\text { Production } \\
\text { in '000 ton }\end{array}$} & \multicolumn{3}{|c|}{ Amount of nitrogen use in 000 ton } & \multirow{2}{*}{$\begin{array}{c}\text { Change in } \\
\text { nitrogen } \\
\text { use in kg } \\
\text { per } 1 \text { ha }\end{array}$} \\
\hline & & & $\begin{array}{c}\text { for 'older' } \\
\text { varieties }\end{array}$ & $\begin{array}{c}\text { for 'newer' } \\
\text { varieties }\end{array}$ & $\begin{array}{c}\text { differenc } \\
e\end{array}$ & \\
\hline $\begin{array}{l}\text { Winter } \\
\text { wheat }\end{array}$ & 1975 & 9607 & 129.8 & 123.2 & -6.6 & $-3,4$ \\
\hline Rye & 787 & 2295 & 28.9 & 27.2 & -1.7 & -2.3 \\
\hline Total & 2762 & 11902 & 158.1 & 147.4 & -8.3 & -3.1 \\
\hline
\end{tabular}

Source: author's calculations

The estimated influence of introduction of new varieties in production on the level of reduction of use of nitrogen in mineral fertilizers was determined to be 8.3 thousand tons per year. This indicates that progress achieved for new varieties in years 1998-2014 with regard to utilization of nitrogen from mineral fertilizers made it possible to reduce fertilizer use by $5.3 \%$. This means it is possible to achieve higher yields without increasing fertilizer use, but also to reduce the fertilization level without reducing production. This may reduce the pressure of agriculture on the natural environment despite increase in production. The above has been confirmed by conclusion of Kopinski (2018) concerning lower emission from farming per unit of production.

\title{
Conclusions
}

Agricultural production, although necessary to feed the human population, exerts substantial impact on the environment as any other human activity. Progress in agriculture may contribute to mitigation of negative external impact, including reduction in pressure on the natural environment due to emission of nitrogen from agricultural sources and emission of greenhouse gases. Biological progress in form of new plant varieties is one of the options for achievement of this objective. The following conclusions have been made in the study.

1) Cereal varieties introduced in Poland in the subsequent years of period 1998-2014 were characterized by increase in ratio of productivity of nitrogen use from mineral fertilizers.

2) The productivity of nitrogen from mineral fertilizers for varieties registered in 2012-2014 was 78 $\mathrm{kg}$ of grain per $1 \mathrm{~kg}$ of nitrogen for winter wheat and $84 \mathrm{~kg}$ of grain per $1 \mathrm{~kg}$ of nitrogen for rye varieties.

3) Throughout the examined period, average nitrogen productivity increased by $0.27 \mathrm{~kg}$ of grain $/ 1$ $\mathrm{kg} \mathrm{N}$ with variety age decrease by 1 year for winter wheat and even as much as $1 \mathrm{~kg}$ of grain /1 $\mathrm{kg} \mathrm{N}$ for rye. In the case of rye, hybrid varieties were characterized by a higher nitrogen utilization ratio in comparison with population varieties, but in both groups, an increase in the ratio was recorded for newer varieties.

4) As a result of replacement of varieties of winter wheat and rye from years 1998-200 with varieties introduced to production in years 2012-2014, it would be possible to reduce nitrogen use in mineral fertilizers by $5.3 \%$ while maintaining cereal production at a constant level.

5) Introduction of biological progress in agricultural production is a substitute of use of inputs from non-renewable resources and contributes to reduction in emission of pollutants from agriculture 
to the natural environment - both air and water, constituting an important aspect of sustainable development of agriculture.

\section{Bibliography}

1. COBORU (2005-2017). Wyniki porejestrowych doswiadczen odmianowych. Zboza ozime (Results of PostRegistration Variety Testing. Winter Cereals). Centralny Osrodek Badania Odmian Roslin Uprawnych: Slupia Wielka.

2. Czyzewski, A., Staniszewski, J. (2018). Zrownowazona intensyfikacja rolnictwa jako kombinacja efektywnosci nakladow ekonomicznych i srodowiskowych (Sustainable Intensification of Agriculture as the Composition of Economic Productivity and Environmental Pressure Measures). Zeszyty Naukowe SGGW w Warszawie - Problemy Rolnictwa Swiatowego, 18(33) (3), pp. 80-90. DOI: 10.22630/PRS.2018.18.3.68

3. Danilowska, A. (2015). Provision of Public Goods by Agriculture in Poland. Economic Science for Rural Development, No. 37, pp. 142-151. Available from: http://llufb.Ilu.Iv/conference/economic_science_rural/2015/Latvia_ESRD_37_2015-142-151.pdf

4. Dawson, J. C., Huggins, D. R., Jones, S. S. (2008). Characterizing Nitrogen Use Efficiency in Natural and Agricultural Ecosystems to Improve the Performance of Cereal Crops in Low-input and Organic Agricultural Systems. Field Crops Research, 107(2), pp. 89-101. https://doi.org/10.1016/j.fcr.2008.01.001

5. Duvick, D. (2005). The Contribution of Breeding to Yield Advances in Maize (Zea Mays L.). Advances in Agronomy, 86, pp. 83-145. DOI: 10.1016/S0065-2113(05)86002-X

6. Faber, A., Jarosz, Z. (2018). Modelowanie emisji podtlenku azotu i amoniaku w skali regionalnej oraz w Polsce (Modeling of Soil Organic Carbon Balance and Greenhouse Gas Emissions on a Regional Scale and in Poland). Zeszyty Naukowe SGGW w Warszawie - Problemy Rolnictwa Swiatowego, 18(33) (2), pp. 70-81. DOI: $10.22630 / P R S .2018 .18 .2 .35$

7. Gastal, F., Lemaire, G., Durand, J. L., Louarn, G. (2015). Quantifying Crop Responses to Nitrogen and Avenues to Improve Nitrogen-use Efficiency. In Crop Physiology, (Second Edition), pp. 161-206. DOI: $10.1016 /$ B978-0-12-417104-6.00008-X

8. Gołębiewska, B., Pajewski, T. (2018). Positive and Negative Externalities of Management Illustrated by the Case of Agricultural Production. Journal of Agribusiness and Rural Development, (2 (48)), 113-120. DOI: $10.17306 /$ J.JARD.2018.00395

9. Guarda, G., Padovan, S., Delogu, G. (2004). Grain Yield, Nitrogen-use Efficiency and Baking Quality of Old and Modern Italian Bread-wheat Cultivars Grown at Different Nitrogen Levels. European Journal of Agronomy, 21(2), pp. 181-192. DOI: 10.1016/j.eja.2003.08.001

10. Hitz, K., Clark, A. J., Van Sanford, D. A. (2017). Identifying Nitrogen-use Efficient Soft Red Winter Wheat Lines in High and Low Nitrogen Environments. Field crops research, 200, pp. 1-9. DOI: $10.1016 / j . f c r .2016 .10 .001$

11.Jankowiak, J., Bienkowski, J., Kolka, M. (2010). Wplyw intensywnosci produkcji rolnej na emisje azotu do srodowiska (The Effect of Agricultural Production Intensity on the Nitrogen Emission Into the Environment). Roczniki Naukowe Stowarzyszenia Ekonomistow Rolnictwa i Agrobiznesu, 12(1), pp. 65-69.

12. Klikocka, H., Glowacka, A., Juszczak, D. (2011). Wplyw zroznicowanych sposobow uprawy roli i nawozenia mineralnego na efekty ekonomiczne uprawy jeczmienia jarego (The Influence of Different Soil Tillage Methods and Mineral Fertilization on the Economic Parameter of Spring Barley). Fragm. Agron., 28(2), pp. 44-54.

13. Kopinski, J. (2018). Ocena zmian organizacyjno-produkcyjnych w polskim rolnictwie w kontekscie wybranych oddzialywan srodowiskowych (Assessment of Organizational and Production Changes in Polish Agriculture in the Context of Selected Environmental Impacts). Zeszyty Naukowe SGGW w Warszawie Problemy Rolnictwa Swiatowego, 18(33) (4), pp. 284-294. DOI: 10.22630/PRS.2018.18.4.118

14. Kraciuk, J. (2018). Bezpieczenstwo zywnosciowe Polski na tle wybranych krajow Europy Wschodniej (Food Security in the Selected Countries of Eastern Europe). Zeszyty Naukowe SGGW - Ekonomika i Organizacja Gospodarki Zywnościowej, (121), 41-53. DOI: 10.22630/EIOGZ.2018.121.3

15. Le Gouis, J., Béghin, D., Heumez, E., Pluchard, p. (2000). Genetic Differences for Nitrogen Uptake and Nitrogen Utilisation Efficiencies in Winter Wheat. European Journal of Agronomy, 12(3-4), 163-173. DOI: 10.1016/S1161-0301(00)00045-9

16. Lenerts, A. Popluga, D., Rivza, p. (2017). Selection of Greenhouse Gas Emission-Reducing Measures with Analytical Hierarchy Process Approach: A Case Study From Latvian Crop Production Sector. Economic Science For Rural Development, No. 44, pp. 267-273. Available at: http://llufb.Ilu.Iv/conference/economic_science_rural/2017/Latvia_ESRD_44_2017-267-273.pdf

17. Malazewska, S. (2015). Srodowiskowe dobra publiczne w rolnictwie i na obszarach wiejskich (Environmental Public Goods in Agriculture and Rural Areas). Ekonomia i Srodowisko, No. 1, pp. 132-147.

18. Naglis-Liepa, K., Popluga, D., Lenerts, A., Rivza, P., Kreismane, D. (2018). Integrated Impact Assessment of Agricultural GHG Abatement Measures. Economic Science for Rural Development, No. 49, pp. 77-83. DOI: $10.22616 / E S R D .2018 .121$

19. Ortiz-Monasterio, R., Sayre, K. D., Rajaram, S., \& McMahon, M., 1997. Genetic Progress in Wheat Yield and Nitrogen Use Efficiency Under Four Nitrogen Rates. Crop Science, 37(3), 898-904. DOI: $10.2135 /$ cropsci1997.0011183X003700030033x

20. Raun, W. R., Johnson, G. V. 1999. Improving Nitrogen Use Efficiency for Cereal Production. Agronomy Journal, 91(3), pp. 357-363. DOI: 10.2134/agronj1999.00021962009100030001x 
21. Stevenson, J., Villoria, N., Byerlee, D., Kelley, T., Maredia, M. (2013). Green Revolution Research Saved an Estimated 18 to 27 Million Hectares from Being Brought into Agricultural Production. Proceedings of the National Academy of Sciences of the United States of America,110(21),pp.8363-8368.

DOI: $10.1073 /$ pnas.1208065110

22. Thirtle, C. (1995). Technological Change and the Productivity Slowdown in Field Crops: United States, 193978. Southern Journal of Agricultural Economics, No. 17 (Dec.), pp. 33-42. DOI: $10.1017 /$ S0081305200025036

23.Tkaczyk, P., Bednarek, W., Brodowska, M., Muszynski, p. (2018). Fosforany i azotany (V) w wodach gruntowych jako element zanieczyszczenia srodowiska przyrodniczego (Phosphates and Nitrates $(V)$ in Groundwater as an Element of Natural Environment Pollution). Annales UMCS sectio E Agricultura, 73(4), pp. 149-159. DOI: $10.24326 /$ asx.2018.4.13

24. Van Sanford, D. A., MacKown, C. T. (1986). Variation in Nitrogen Use Efficiency Among Soft Red Winter Wheat Genotypes. Theoretical and Applied Genetics, 72(2), pp. 158-163. DOI: 10.1007/BF00266987

25. Wicka, A. (2018). Crop Insurance With Subsidies in Poland - Do It Works? Economic Science for Rural Development, (49), pp. 178-186. DOI: 10.22616/ESRD.2018.134

26. Wicki, L. (2016). Wykorzystanie potencjalu plonowania zboz w produkcji rolniczej w Polsce (The Level of Utilization of Potential of Yielding of Cereals Species in Poland). Roczniki Naukowe Stowarzyszenia Ekonomistow Rolnictwa i Agrobiznesu, 18(5), pp. 267-273.

27. Wicki, L. (2017a). Postep w plonowaniu odmian pszenicy ozimej i zyta w doswiadczeniach odmianowych w Polsce. (Changes in Yielding of Varieties of Winter Wheat and Rye in Variety Testing in Poland). Roczniki Naukowe Stowarzyszenia Ekonomistow Rolnictwa i Agrobiznesu, 19(4), pp. 224-230. DOI: 10.5604/01.3001.0010.5191

28. Wicki, L. (2017b). Poziom i zakres wsparcia upowszechniania postepu biologicznego w produkcji roslinnej w ramach dzialan Agencji Rynku Rolnego (The Level and Scope of Support of Biological Progress Dissemination in Crop Production in Poland Within the Measures of Agricultural Market Agency). Zeszyty Naukowe SGGW, Polityki Europejskie, Finanse i Marketing, No. 18(67), pp. 259-271. DOI: 10.22630/PEFIM.2017.18.67.38

29. Wicki, L. (2018a). The Role of Productivity Growth in Agricultural Production Development in the Central and Eastern Europe Countries After 1991. Economic Science for Rural Development, No. 47, pp. 514-523. DOI: $10.22616 / E S R D .2018 .060$

30. Wicki, L. (2018b). Znaczenie postepu biologicznego we wzroscie plonowania zboz jarych w doswiadczeniach odmianowych w Polsce (The Role of Biological Progress in the Increase of the Yield of Spring Cereals in Varietal Testing in Poland). Roczniki Naukowe Stowarzyszenia Ekonomistow Rolnictwa i Agrobiznesu, 20(2), pp. 162-168. DOI: 10.5604/01.3001.0011.8132 